\title{
Upregulated pneumococcal adhesion molecule (platelet-activating factor receptor) may predispose COPD patients to community-acquired pneumonia
}

This article was published in the following Dove Press journal:

International Journal of COPD

24 October 2017

Number of times this article has been viewed

\author{
Shakti Dhar Shukla ${ }^{1,2}$ \\ Philip M Hansbro', ${ }^{1,2}$ \\ Eugene Haydn Walters ${ }^{3}$ \\ 'School of Biomedical Sciences \\ and Pharmacy, The University of \\ Newcastle, Callaghan, ${ }^{2}$ Hunter \\ Medical Research Institute, New \\ Lambton Heights, NSW, ${ }^{3}$ School of \\ Medicine, University of Tasmania, \\ Hobart, TAS, Australia
}

\section{Dear editor}

We read with great interest the recent paper by Braeken et al which analyzed the associations between COPD and community-acquired pneumonia (CAP), published in your journal. ${ }^{1}$ In this large population-based study, the authors have concluded that the risk of CAP increases fourfold in patients with COPD, independent of smoking status. The authors briefly discuss potential smoking-induced mechanisms leading to increased risk of CAP in COPD, such as host physiological and structural changes, increased bacterial virulence and impaired host immunity. The authors also stress the need for further mechanistic studies on the cause of this increased risk of CAP in COPD patients. ${ }^{1}$

We believe that some of our recent work is relevant to these findings. We have published several studies that have found increased respiratory tract epithelial expression of specific bacterial adhesion factors in COPD, in particular platelet-activating factor receptor (PAFr) which is the major pneumococcal and Haemophilus influenzae adhesion molecule. ${ }^{2,3}$ This could well be one important mechanism that the authors did not mention that could significantly increase the risk of Streptococcus pneumoniae respiratory infection in COPD. Pack-years of smoking were strongly related to epithelial PAFr protein levels in COPD patients. ${ }^{2}$ Notably, S. pneumoniae expresses phosphorylcholine in its cell wall that specifically binds to PAFr, leading to initial attachment and subsequent translocation of bacteria into deeper tissue.

In addition, cultured respiratory epithelial cells exposed to cigarette smoke extract exhibited significantly increased PAFr protein expression and greater $S$. pneumoniae adhesion. Notably, blocking PAFr by specific PAFr-antagonist (WEB-2086) reduced adherence of $S$. pneumoniae to the levels seen in control cells. ${ }^{4}$ This opens the possibility that PAFr could be targeted therapeutically in COPD patients to limit chronic bacterial adhesion and potentially acute exacerbations, but also CAP in this vulnerable population.

Translational research in this area of bacterial-epithelial interactions is still in its infancy but has huge potential to provide novel insights into COPD pathogenesis and its natural history, as well as new therapeutic targets. Blocking the initial stages of bacterial adhesion and colonization in already activated epithelium in COPD patients could emerge as a promising target for the development of alternate, non-antibiotic pharmacotherapies for the management of the disease and its infective complication. ${ }^{5}$ Preliminary data in both in vitro and in vivo models is so promising that further clinical
Correspondence: Eugene Haydn Walters School of Medicine, University of Tasmania, 17 Liverpool Street, Private Bag 23, Hobart, TAS 7000, Australia Email haydn.walters@utas.edu.au 
research on anti-PAFr therapies is now warranted to ascertain their efficacy in preventing and treating bacterial infections in COPD. There may be broader application to other chronic respiratory diseases, such cystic fibrosis, given that Pseudomonas aeruginosa is the third "common respiratory pathogen" that also adheres to PAFr. Indeed, there seems to be no other obvious mechanism that links these three quite disparate organisms, making them so dangerous to the respiratory tract in very particular circumstances.

\section{Disclosure}

The authors report no conflicts of interest in this communication.

\section{References}

1. Braeken DC, Rohde GG, Franssen FM, et al. Risk of community-acquired pneumonia in chronic obstructive pulmonary disease stratified by smoking status: a population-based cohort study in the United Kingdom. Int J Chron Obstruct Pulmon Dis. 2017;12:2425-2432.
2. Shukla SD, Muller HK, Latham R, Sohal SS, Walters EH. Plateletactivating factor receptor (PAFr) is upregulated in small airways and alveoli of smokers and COPD patients. Respirology. 2016;21(3): 504-510.

3. Shukla SD, Sohal SS, Mahmood MQ, Reid D, Muller HK, Walters EH. Airway epithelial platelet-activating factor receptor expression is markedly upregulated in chronic obstructive pulmonary disease. Int $J$ Chron Obstruct Pulmon Dis. 2014;9:853-861.

4. Shukla SD, Fairbairn RL, Gell DA, et al. An antagonist of the plateletactivating factor receptor inhibits adherence of both nontypeable Haemophilus influenzae and Streptococcus pneumoniae to cultured human bronchial epithelial cells exposed to cigarette smoke. Int J Chron Obstruct Pulmon Dis. 2016;11:1647-1655.

5. Kc R, Shukla SD, Walters EH, O'Toole RF. Temporal upregulation of host surface receptors provides a window of opportunity for bacterial adhesion and disease. Microbiology. 2017;163(4):421-430. 


\section{Authors' reply}

Frank de Vries ${ }^{1,2}$

Gernot GU Rohde ${ }^{3,4}$

Dionne CW Braeken ${ }^{1,4,5}$

Tjeerd $P$ van Staa ${ }^{1,6}$

Patrick C Souverein'

Emiel FM Wouters $\mathrm{s}^{4,5}$

Frits ME Franssen ${ }^{4,5}$

'Division of Pharmacoepidemiology and Clinical Pharmacology, Utrecht Institute for Pharmaceutical Sciences, Utrecht,

2Department of Clinical Pharmacy and Toxicology, Maastricht University Medical Centre (MUMC+), Maastricht, the Netherlands; ${ }^{3}$ Klinikum der Johann Wolfgang Goethe-Universität, Frankfurt am Main, Germany; ${ }^{4}$ Department of Respiratory Medicine, Maastricht University Medical Centre (MUMC+), Maastricht, ${ }^{5}$ Department of Research and Education, CIRO, Horn, the Netherlands;

${ }^{6}$ Department of Health eResearch, University of Manchester, Manchester, UK

\section{Correspondence: Frank de Vries}

Division of Pharmacoepidemiology and Clinical Pharmacology,

Utrecht Institute for Pharmaceutical Sciences, Utrecht University,

PO box 80082, 3508 TB Utrecht, the Netherlands

Tel +3I 302537324

Fax +31302539166

Email f.devries@uu.nl

\section{Dear editor}

We would like to thank Shukla et al for their interesting and valuable addition to our study, which showed that the risk of community-acquired pneumonia (CAP) was fourfold increased among patients with COPD, regardless of their smoking status. ${ }^{1}$ They first speculate that their observation of expression of adhesion molecules (PAFr) in several bacteria that can cause CAP among COPD patients may explain our findings. Although they observed a significantly increased expression of PAFr among smokers with COPD versus smokers with a normal lung function, PAFr expression was not elevated among COPD patients who were ex-smokers. ${ }^{2}$
Thus, these observations are not supportive of the fourfold increased risk of CAP among patients with COPD regardless of their smoking status. ${ }^{2}$ Also, they are not in line with another study by the same group ${ }^{4}$ in which there was no difference in in vivo expression of PAFr between current- and ex-smoking COPD patients. It should also be noted that there is limited comparability between both study populations: while nonsmall-cell lung cancer was an inclusion criterion in the study by Shukla et al, ${ }^{2}$ we evaluated COPD and non-COPD patients from the general population, and only $13 \%-14 \%$ had a history of any malignancy, excluding non-melanoma skin cancer. ${ }^{2}$ The hypothesis by Shukla et al is also not supported by their observation that a 6-month intervention with inhaled corticosteroids (ICS) did not affect PAFr expression, while ICS use is a well-established risk factor of CAP in patients with COPD. ${ }^{3,4}$ Thus, while the hypothesis is interesting, it certainly requires more and larger clinical studies.

\section{Disclosure}

The authors report no conflicts of interest in this communication.

\section{References}

1. Braeken DC, Rohde GG, Franssen FM, et al. Risk of community-acquired pneumonia in chronic obstructive pulmonary disease stratified by smoking status: a population-based cohort study in the United Kingdom. Int J Chron Obstruct Pulmon Dis. 2017;12:2425-2432.

2. Shukla SD, Muller HK, Latham R, Sohal SS, Walters EH. Plateletactivating factor receptor (PAFr) is upregulated in small airways and alveoli of smokers and COPD patients. Respirology. 2016;21(3): 504-510.

3. Shukla SD, Sohal SS, Mahmood MQ, Reid D, Muller HK, Walters EH. Airway epithelial platelet-activating factor receptor expression is markedly upregulated in chronic obstructive pulmonary disease. Int $J$ Chron Obstruct Pulmon Dis. 2014;9:853-861.

4. Kew KM, Seniukovich A. Inhaled steroids and risk of pneumonia for chronic obstructive pulmonary disease. Cochrane Database Syst Rev. 2014; (3):CD010115.

Dove Medical Press encourages responsible, free and frank academic debate. The content of the International Journal of Chronic Obstructive Pulmonary Disease 'letters to the editor' section does not necessarily represent the views of Dove Medical Press, its officers, agents, employees, related entities or the International Journal of Chronic Obstructive Pulmonary Disease editors. While all reasonable steps have been taken to confirm the content of each letter, Dove Medical Press accepts no liability in respect of the content of any letter, nor is it responsible for the content and accuracy of any letter to the editor.

International Journal of COPD

\section{Publish your work in this journal}

The International Journal of COPD is an international, peer-reviewed journal of therapeutics and pharmacology focusing on concise rapid reporting of clinical studies and reviews in COPD. Special focus is given to the pathophysiological processes underlying the disease, intervention programs, patient focused education, and self management protocols.

\section{Dovepress}

This journal is indexed on PubMed Central, MedLine and CAS. The manuscript management system is completely online and includes a very quick and fair peer-review system, which is all easy to use. Visit $\mathrm{http}: / / \mathrm{www}$. dovepress.com/testimonials.php to read real quotes from published authors. 